\title{
Alternative Dispute Resolution for Islamic Finance in Malaysia
}

\author{
N. Khalidah Dahlan ${ }^{1, *}$ \\ ${ }^{1}$ Institute of Malaysian and International Studies (IKMAS), Universiti Kebangsaan Malaysia, 43600 Bangi, Selangor.
}

\begin{abstract}
The law lays down rules that govern private disputes, self-help actions or open-conflicts that may occur in the society. Here, courts, tribunals, arbitration and other dispute resolution forums are the main secular institutions in dispensing just resolutions in a society. As important as the court proceedings, Alternative Dispute Resolution (ADR) process is neutral, it is like a judge who served as the finder of fact and decision maker for the parties involved. By adapting the ADR methods in resolving the disputes relating to Islamic financial products, this method will able to fulfil with the demands on Islamic financial markets in Malaysia. As the highest law of the land places Islam, the religion associated with one of the main ethnicity, as the official religion of the nation and allowed the duality of economic system, in particular banking system, in which conventional banking system exists side-by-side with the Shariacompliant, Islamic banking. This paper will reviewing the pertinent literature on the development of Islamic banking cases, the Alternative dispute resolution methods on Islamic banking and its contributions to Malaysian society regardless of ethnicity and religion. The discussion in this paper therefore will be directed towards highlighting the alternative dispute resolution methods on Islamic banking and its implication to enhance the application of Islamic banking laws to consumers regardless of ethnicity and religion, in order to maintaining fairness and justice in a multi-ethnic society.
\end{abstract}

\section{The Alternative Solutions (Alternative Dispute Resolution) For Any Disputes}

The objective of dispute resolution is to solve the dispute between the parties who seek justice [1]. Who has suffered injury or loss and wanted to claim or refunded any damage or loss that they obtained. Alternative Dispute Resolution (ADR) is a quick way to resolve the dispute, based on freedom of choice on the laws and procedures of their dispute. There are other dispute resolution mechanisms available to the parties to resolve their disputes without going to court.

Over 1,400 years ago, ADR methods have been used by Muslims to settle their differences amicably and this method has been encouraged by Islam and considered as a source of legislation. This is because Islam is a religion that emphasizes the concept of harmony instead of hostilities and embrace the principle of compromise rather than confrontation.

Justice without trial court was raised by Roscoe Pounds since 1912, he said that the court was crowded; delay in the trial is endemic; high costs; shortage of lawyers; overall substantive legislation that traditional legal and not current. Even Pound also said there is a difference in the usage and adoption of legislation among wealthy or poor. This is because the practice of law itself is often dominated by the rich for their favour. Clearly that the justice of the law does not guarantee equality of the overall concept [2].

Pound had put the two concepts of 'justice without law' and 'justice according to law'. As dissatisfaction with legal institutions increased in the early decades of the twentieth century, there was renewed interest in alternatives to litigation, particularly Conciliation and Arbitration [3-4]. Both were touted as a quick, inexpensive procedure to waive counsel, the delay in the trial would result in an expensive cost to produce legal action.

'Alternative dispute resolution' or ADR is described as an alternative way other than through a court case to resolve the problems of the parties involved. Some examples of ADR done to solve the Islamic finance disputes are the Arbitration (tahkim), mediation, conciliation and sulh methods.

\section{Sects' view on Alternative Dispute Resolution Methods}

Each view of the four sects have different views in regards to alternative dispute resolution methods, especially methods of arbitration. Aishath Muneeza explains that the method of alternative dispute resolution, particularly arbitration method according to the Hanafi school is a contract in which the parties involved would prefer a more open and achieved mutual consent on that particular matter [5]. An arbitrator will act as the representative of the parties involved and due to that the decision reached by the arbitration method has a lower level authority than a court's judgment.

According to Maliki, an arbitrator may be selected by any of the parties involved and the appointment of

\footnotetext{
${ }^{1}$ Corresponding author: mr_palil@ukm.my
} 
an arbitrator cannot cancelled the proceedings once it have been commenced. Based on Shafie sect, the arbitration proceedings are different from the process of a court proceedings. An arbitrator can change a decision before they issued a valid arbitration decision. Finally, in Hambali, the alternative dispute resolution methods such as arbitration rules have the same effect as the process of a court proceedings. Therefore, an arbitrator shall have the same qualifications as a judge and any decision made by him will bind all the parties involved.

Conflicts or disputes often occur in a community or in the family institution. Noone described a dispute between individuals resulting from certain conflicts which is inevitable and is considered as a normal scenario in life [6]. Often methods of conflict resolution in the community involving court institution, nonetheless the concept of alternative dispute resolution (ADR) has long been practiced in the community. For example, most societies, nations and religions of the world have been adopting the rules in religion or tradition to resolve their disputes (civil) (each nation and religion has its own terms in implementing this practice). As stated by Syed Khalid Rashid, traditionally the Chinese people using nonlitigation settlement [7]. Their method is to negotiate peace (Youhao Xieshang which means friendly consultation). This method is carried out as a first step to resolve the dispute in the field of commercial, industrial, family and neighbourhood communities.

In Malaysia, since the time of the Malacca sultanate, peaceful settlement of disputes has been practiced. This practice has been incorporated in accordance with the teachings of Islam which demands the issue of musyawarah. The practice of alternative dispute resolution remain intact from the colonial period until today. Now, one of the alternative dispute resolution method which had been adapted with the court proceeding (Sulh method) had been proven and accepted as practice to achieve solution for family cases in the courts of law in several states in Malaysia.

\section{Alternative dispute resolution for Islamic finance disputes}

The Malaysian regulatory framework provides two mechanisms for settlement of disputes in Islamic banking. The mechanisms are litigation and arbitration in which had been provided in Section 56 of the Central Bank Act 2009. The provision states that any proceedings relating to Islamic banking and finance can be made through the courts and arbitration rules. However the proceedings must be in reference to the Syariah Advisory Council [8]. In fact, with reference to the decision in the case of Bank Islam Malaysia Bhd vs. Adnan bin Omar (1994), the parties may choose to settle their disputes on Islamic finance matters thru arbitration method or mediation method provided that such provision should have included in the agreement (section 24 (4) )of the Courts of Judicature Act 1964).
During the proceeding of arbitration or mediation, the parties involved have the right to choose an arbitrator or mediator who specializes in Islamic finance to resolve the case. The arbitrator or the mediator's decision is final and there is no need to refer the court [8].

According to Sundra Rajo (director of the Kuala Lumpur Regional Centre for Arbitration KLRCA) [9], stated that the statistics of cases registered for the arbitration rules were 85 cases in 2012, while in 2013, registered a case for using arbitration tara is growing by about 110 cases. This includes $20 \%$ of them were international cases. In fact, there are many Malaysian researcher have revealed their finding that Malaysian society is now increasingly exploring other methods to settle their dispute and not only seeking solutions in court $[5,7,10,11]$. Other researches that also indicated the method of alternative dispute resolution are such as mediation method [12], mediation and arbitration method [13], Sulh method [14-15] and [1617] and lastly research on the arbitration rules adopted globally [18].

According to Umar Oseni [11], any disputes that resolved through an alternative dispute resolution is considered as a better solution. Especially, a mediation session that lead by a private negotiations in which the dispute is chaired by third parties. For example cases involving improper management of Waqf properties are better resolved through alternative dispute resolution instead of through a declaration by the court.

The proceeding of mediation and sulh method in Sharia law involve actions for compromise, which is a practical demonstration of the give-and-take the initiative. Furthermore in Malaysia, all disputes relating to the issue of Islamic finance will continue to refer to the Shariah Advisory Council of Bank Negara. Therefore, if the parties involved choose to solve their dispute thru alternative dispute resolution in which this case is the Sulh method, the Sulh officer will refer to the Shariah Advisory Council of Bank Negara to help reduce the number of problems that exist in Islamic finance industry in Malaysia.

The initiative to establish a system of Alternative Dispute Resolution to help speed up and reduce the backlog of cases leads to the implementation of Sulh in the Syariah Court. This idea is also driven by the effectiveness implementation of the mediation method practiced in other countries. Despite that, Sulh and mediation methods have different names but the purpose and objectives of their practice are the same, the parties settle the dispute by binding memorandum of understanding.

\section{The Evolution On Civil Law And Islamic Law In Dealing With Islamic Banking Transactions.}

Clash of Sharia and civil courts jurisdictions has given rise to a number of problems, especially when it comes to litigation procedures. According to Zainal Amin Ayub [19], there should be harmonization of aspects of 
civil litigation, especially the discovery and appeal procedures, with the procedures currently in use in the Sharia courts, which are based on the precepts of Islamic law. There are also opinions that the presence of Sharia experts in the civil High Court is necessary. In relation to Islamic banking cases, this would create a hybrid legal system whereby there would be two courts - the civil court and the Sharia court - which have parallel jurisdictions in the field of Islamic banking [20].

Previously, Court cases involving Islamic banking issues had often brought to the limelight the issue of clash of jurisdiction of civil court and Sharia court. Among the cases wherein this issue was raised are Tinta Press Sdn Bhd v Bank Islam (M) Bhd (1987), Bank Islam Malaysia Berhad v. Adnan Omar (1994), Dato 'Nik Mahmud Bin Daud v Bank Islam Malaysia Berhad (1996), Bank Malaysia Bhd v Emcee Corporation Sdn Bhd (2003), Bank Islam Malaysia Bhd v. Pasar raya Peladang Sdn Bhd. (2004), Arab Malaysian Merchant Bank Bhd v Silver Concept Sdn Bhd (2005), Malayan Banking Bhd v Ya'kub Oje \& Anor (2007).

Overall the majority of cases involving Islamic banking often include restrictions on the deep understanding of the legal system and also in terms of Islamic banking practices, namely in the form of technical documentation. Appreciation and analysis of these cases were also formulated by Rusni Hassan [20] that serious obstacles faced in Islamic banking in Malaysia is an obstacle in the legal system and barriers in the documentation.

Barriers in the legal system is basically related to the Islamic Banking Act 1983, Takaful Act and other acts relating to Islamic banking law in Malaysia. Before the start of the Islamic banking in Malaysia, all legislation in the banking business is based on civil law. And this has given rise to barriers to Islamic banking. This can be seen by the cases decided in court. For example, in the case of Bank Islam Malaysia Bhd v Adnan bin Omar (1994), there is a dispute of Order 83 Rules of the High Court 1980 where interest or usury should be investigated practice. This is because the practice of usury is contrary to the principles and laws of the Islamic financial system.

Obstacles in the documentation shows that the accuracy in a contract that would reflect the intention of the parties. Where for some other it reflects a contract that involves a complicated procedure. In Islamic banking, content and order of documents also represent an important aspect. An Islamic banking documents shall be valid and lawful under the laws of Islam. As a result, the burden of drafting documentation for Islamic banking business is very hig Obstacles encountered in the documentation of Islamic banking in Malaysia can be seen through the results of the case by the court. For example, in the case of Malayan Banking Bhd v Ho Marilyn Siok Lin (2006), Islamic banking documents submitted to the court has proved that this case does not have the compatibility of Sharia perspective. This is because the main purpose of the document is not explicitly stated. It becomes more difficult when someone who does not understand the amenities in product Bai Bithaman Ajil drafting the document and gave it to clients who are not Muslims. As a result, the documentation that is designed to have failed to reach their objectives and reflect the intention of the parties.

Nonetheless, the issue of homogenization of Islamic banking products offered by all financial institutions in Malaysia is however far from being resolved. Commonly all the legal documents are in English (Civil Procedurals) and common law lawyers who draft those documents could not appear in the Sharia courts. The law is an English law, not a Sharia law. However, the current ongoing harmonization of civil procedural and substantive laws to accommodate the Sharia peculiarities of Islamic banking principles and practices implies that instances of clashes of jurisdictions between the civil and Sharia courts will be a thing of the past in the nearest future. This harmonization process has addressed the concern of Islamic banking consumers that they are being denied the full measure of justice they deserve [22].

After researching a number of court cases in Malaysian legal system on the issue of financial law, especially in the issue of Islamic banking has also undergone a transformation in the dispute resolution process between civil law and Syariah law. However, effective dispute resolution and with a strong foundation is needed to ensure that the Islamic financial system to meet the needs of each nation and religion in order to achieve the demands of the market, justice and equality. It is evident that Islamic banking law and practice are currently undergoing a transformation process which will make them compatible with the civil law. The challenge is to ensure that the transformed Islamic banking law and practice meet the needs of the market demands and the way of life, if it is to achieve equality for all races and religions.

Looking at the diversity of barriers in the legal framework, Islamic finance may be required by a method other than through court proceedings to resolve the dispute by means of alternative dispute resolution (ADR). Alternative dispute resolution can be defined as a procedure that acts as an alternative to legal action to resolve disputes. It can be formal (e.g. arbitration rules) or informal (e.g. methods of negotiation and mediation), and is a private process and its decision will be binding ADR process when done. The dispute has been settled will be given an award which is made by a process which independent tribunal (e.g. by an arbitrator, mediator and more).

\section{Conclusion}

In general, the differences between solving dispute thru court proceedings and the Alternative Dispute Resolution are more focused on the operation procedures and its impact towards the parties involved. Not to mention as well as the role and decisions made by a third party (the judge / arbitrator / conciliator / 
mediators / Sulh officer). During the process of Alternative Dispute Resolution method, the third party will become as the facilitator, decision makers and problem solver for the parties involved in order to reach a decision [23]. Moreover, the Alternative Dispute Resolution process must be carried out with the consent of both parties and it is binding between the parties. Except when there is a reasonable doubt in which the decision had been made fraudulently and bias. This method is vital to achieve good relationship between both sides [24].

Arbitration and mediation are often practiced in Malaysia when involved with financial disputes. Arbitration is a dispute resolution methods that involve disputants present their cases before an independent tribunal, impartiality and an expert who has knowledge of the law. When inspecting the facts in that case the arbitrator will make a decision. If the parties involved have agreed the decision would be binding on the parties. Unlike the methods of mediation is a process in which a third party would be a neutral party for the parties to a dispute to reach an agreed settlement to their conflict.

Most of the disputes associated with Islamic financial transactions in the court, will refer to specialists such as the Shariah Advisory Council of Bank Negara Malaysia. Therefore, the expertise of the Shariah Advisory Council of Bank Negara Malaysia plays an important role in helping to reduce the problems that exist in the Islamic finance industry in Malaysia. So it is not an impossible matter if their expertise can also be practiced through alternative dispute resolution methods. With further research on the Alternative Dispute Resolution method (namely judgement without a court trial), it can be expected to become not only as the alternative way but it will become one of the main methods in the future to solve the disputes in the Islamic financial system.

\section{References}

1. J. Rawls, 'Justice as Fairness: Physical not Metaphysical'. In Thomas Morawetz. Justice. (England: Datmouth Publishing Co. Ltd. 1998)

2. P., Roscoe., Mo. Bar Ass'n Proc., 110, 112; Reginald Heber Smith, Justice and the Poor 15 (1919)

3. Pound, Roscoe., The limits of effective legal action, 3 American Bar Ass'n J. (Jan 1917), 55-57; (1917)

4. Pound, 1922. An introduction to the philosophy of law (new haven, 1922), 54 (1922)

5. A. Muneeza, Malayan Law Journal Articles, 4, 2. (2010)

6. Noone, M., Australian Dispute Resolution Journal, 17, 96-100 (2006)

7. Rashid, S.K., Alternative dispute resolution: The emerging new trend of informal justice. (Kuala Lumpur: International Islamic University Malaysia, 2002)
8. H. Rusni, M. A. Hussain, A. Yusoff, 25 KANUN (1). June 2013: 83-106. (2013)

9. Anon, Datuk Sundra Rajoo's Speech at the Launch of KLRCA's Revised Rules 2013. http://klrca.org/speeches/datuk-sundra-rajoosspeech-at-the-launch-of-klrcas-revised-rules2013/ (2013)

10. M. Surianom, A. H. Nor 'Adha, The Second Asian Business and Management Conference 2011, 224234, ISSN: 2186-5914, Proceedings URL: http://iafor.org/abmc_proceedings.html (2011)

11. U.A. Oseni, (2012)

12. P. G. Lim., Malayan Law Journal 4 (cv-cxii.) (1998)

13. Bukhari, K. Zaman, In 8th general Assembly 2003 by Badan Peguam Malaysia. (2003)

14. A. Raihanah, Kertas Kerja Seminar Isu-isu Mahkamah Syariah VII. Anjuran Universiti Islam Antarabangsa Malaysia, (2005)

15. A. Raihanah,. Sulh Dalam Kes Kekeluargaan Islam, (Kuala Lumpur: Penerbit Universiti Malaya 2008)

16. Safei, S. A., Int. Sem. Comp. L., 237. (2008)

17. M. R. Zainudin, Muzakarah Pegawai-Pegawai Sulh Seluruh Malaysia (Kali Pertama) Anjuran Hotel Royal Penang, Pulau Pinang, (2009)

18. Saleh, S. Commercial Arbitration in the Arab Middle East: Jordan, Kuwait, Bahrain, and Saudi Arabia. (United Kingdom: Aseanlex Ltd., 2011)

19. Ayub, Z. A. Hussain, M. Azam. A. Shariff, Nurretina, Ali, Hassan, 2 CLJ ix ( 2007)

20. Shariff, M. Ismail, 1 MLJ cxiv (1998)

21. Hassan, R., 5 MLJ ixxx \& 6. (2011)

22. Markom, Ruzian. Pitchay, S. Ali. Zainol, Z. Ashiqin. A. Rahim, Anita. A.R. Merican, R. Merican. Eur. J. L. Eco. Spr. (2012)

23. A. Adam., J. Legal Aspets Sports. 12, 153-182. (2002)

24. Jady@ Z. Hassim, K.H. Hassan, Z. Z. Ashiqin. Penyelesaian Pertikaian Mekanisme dan Perundangan, 93-111. (Bangi: Penerbit Universiti Kebangsaan Malaysia, 2014) 